\title{
Notes
}

\section{Symposium on Soft Contact Lenses}

Birmingham, December 20, 1972

At a symposium on the Soft Contact Lens to be held at the University of Aston in Birmingham, the speakers will include Prof. R. M. Hill of Ohio State University and Dr. B. Tighe of the University of Aston. Demonstrations of commercially available forms of soft lenses will be given.

\section{Intraocular Implant Glub Award}

With the help of the Prof. Dr. H. J. Flieringa Foundation, the Intraocular Implant Club offers an Award of at least $\$_{1}, 000$, plus a Medal, for the best original contribution to the field of intraocular artificial lenses. The award is open to every scientific discipline.

The contributions will be evaluated by a committee of well-known scientists, to be appointed by the Board of the Prof. Dr. H. J. Flieringa Foundation, advised by the Intraocular Implant Club. The Award will be presented by a nominee of the Foundation at the International Ophthalmological Congress in Paris, in May, 1974 .

Contributions, which should be sent in a form suitable for publication in one of the ophthalmological journals, should be sent at least 3 months before the opening of the Congress to:

D. P. Choyce, F.R.C.S., Secretary/ Treasurer, Intraocular Implant Club,

9 Drake Road,

Westcliff-on-sea, Essex,

England

\section{Obituary}

\section{Andrew Rugg-Gunn, I884-1972}

Mr. A. Rugg-Gunn, a personality well-known to the older generation of ophthalmologists in London, died on September I, I972, at the age of 87 . He was Scottish by birth and spent his boyhood in the Isle of Skye from which his personality retained a Celtic flavour throughout his life. He graduated from Edinburgh University in 1907 and went into general practice. In the first world war he served at Gallipoli and in India where he acted as an ophthalmic specialist, and on demobilization he came to London where he continued in this specialty in practice and as surgeon to the Western Ophthalmic and Central Middlesex Hospitals. During this period his main interest lay in contact lenses and retinal detachments. Apart from his professional work he played an active part in London medicine, becoming president of the Chelsea Clinical Society and participating in the work of the Medical Society of London, the Hunterian Society, and the Medico-Legal Society, as well as acting as president of the Viking Society for Northern Research, an indication of his interest in Scandinavian history and literature. 